\title{
Sejahtera Bersama Koperasi Di Kecamatan Gedangsari
}

\author{
Fatwa Tentama ${ }^{1}$, Bagus Gumelar ${ }^{2}$, Ahmad Rizal Solihudin ${ }^{3}$ \\ ${ }^{1}$ Fakultas Psikologi, Universitas Ahmad Dahlan Yogyakarta \\ ${ }^{1,2}$ Fakultas Ekonomi, Universitas Ahmad Dahlan Yogyakarta \\ E-mail: fatwa.tentama@psy.uad.ac.id
}

\begin{abstract}
ABSTRAK
Salah satu kendala utama pengembangan ekonomi wilayah Gedangsari adalah akses terhadap modal. Pada dasarnya kendala ini sangat umum dialami oleh masyarakat di wilayah pedesaan. Masyarakat pedesaan masih mengandalkan modal sendiri, pinjam ke orang terdekat atau bahkan seringkali rentenir untuk memulai suatu aktifitas ekonomi (usaha). Perkembangan usaha terhambat bahkan hancur karena permasalahan modal dan pemasaran. Kondisi ini diperparah kurangnya pemahaman masyarakat pedesaan terhadap sumber-sumber pembiayaan lain yang lebih cocok baik dari segi kapasitas maupun risiko. Banyak penelitian mengungkapkan, koperasi sebagai lembaga keuangan mikro cukup tepat untuk wilayah pedesaaan. Selain karena pengurusan dan modal yang relatif mudah dan kecil, koperasi sebagai lembaga keuangan berbasis keanggotaan selaras dengan kondisi sosial masyarakat pedesaan yang mengutamakan kebersamaan dan kekeluargaan. Sampai saat ini banyak koperasi yang berdiri sampai tingkat desa namum kurang dikelola dengan baik. Hal ini berakibat pada kurangnya perannya koperasi dalam usaha mensejahterakan masyarakat. Apabila masyarakat dapat mengelola koperasi dengan baik, tentu saja akan meningkatkan kesejahteraan masyarakat pedesaan. Oleh karena itu perlu adanya pemahaman oleh masyarakat tentang bagaimana mengoptimalkan pengeloaan koperasi yang telah ada sehingga dapat mengingkatkan fungsi dan peran koperasi dalam usaha mensejahterakan masyarakat terutama di Kecamatan Gedangsari. Sasaran dari kegiatan ini adalah masyarakat Kecamatan Gedangsari. Tujuan dari kegiatan ini adalah masyarakat memiliki motivasi untuk berkoperasi, masyarakat mampu menggandeng koperasi untuk pengembangan dan peningkatan hasil atau produk usahanya dan masyarakat dapat mengelola koperasi dengan baik dalam upaya meningkatkan kesejahteraan masyarakat pedesaan. Hasil dari pelatihan ini masyarakat memiliki pemahaman tentang bagaimana mengoptimalkan pengelolaan koperasi yang telah ada sehingga dapat meningkatkan fungsi dan peran koperasi dalam usaha mensejahterakan masyarakat terutama di Kecamatan Gedangsari serta memiliki pengetahuan dan ketrampilan dalam pendirian badan hukum koperasi dan melakukan perhitungan pinjaman pada lembaga keuangan. Selain itu luaran yang dihasilkan adalah publikasi dalam jurnal/proseding dan publikasi kegiatan dalam web / online.
\end{abstract}

Kata Kunci: koperasi, keuangan, kesejahteraan 


\section{PENDAHULUAN}

Salah satu kendala utama pengembangan ekonomi wilayah Gedangsari adalah akses terhadap modal. Pada dasarnya kendala ini sangat umum dialami oleh masyarakat di wilayah pedesaan. Masyarakat pedesaan masih mengandalkan modal sendiri, pinjam ke orang terdekat atau bahkan seringkali rentenir untuk memulai suatu aktifitas ekonomi (usaha). Tentu saja sarana-sarana penyedia pembiayaan tersebut mempunyai keterbatasan (relatif skala kecil) dan risiko yang besar (bunga tinggi pada rentenir). Kondisi ini diperparah kurangnya pemahaman masyarakat pedesaan terhadap sumber-sumber pembiayaan lain yang lebih cocok baik dari segi kapasitas maupun risiko. Oleh karena itu perlu adanya upaya dari pihak pemerintah setempat maupun pihak-pihak terkait (OJK, akademisi, lembaga keuangan) untuk secara sistematik memberi pemahaman masyarakat pedesaan terhadap lembaga-lembaga keuangan. Usaha ini pada akhirnya akan meningkatkan literasi keuangan masyarakat pedesaan dan diharapkan menumbuhkan semangat produktif di wilayah pedesaan terutama di Kecamatan Gedangsari.

Saat ini sudah cukup banyak lembaga dan instrumen keuangan yang bisa diakses oleh masyarakat pedesaan. Beberapa bank sudah membuka kantor sampai tingkat kecamatan, bahkan program laku pandai (counter layanan keuangan) sudah masuk pada tingkat desa. Selain itu, ada juga beberapa lembaga keuangan yang sudah mudah ditemukan sampai tingkat kecamatan seperti koperasi baik yang konvensional maupun syariah (BMT). Banyak penelitian mengungkapkan, koperasi sebagai lembaga keuangan mikro cukup tepat untuk wilayah pedesaaan. Selain karena pengurusan dan modal yang relative mudah dan kecil, koperasi sebagai lembaga keuangan berbasis keanggotaan selaras dengan kondisi sosial masyarakat pedesaan yang mengutamakan kebersamaan dan kekeluargaan.

Koperasi Indonesia tertuang di dalam amanat Undang-undang dasar 1945 pasal 33 ayat 1

yang menyebutkan menyatakan bahwa perekonomian Indonesia disusun sebagai usaha bersama berdasar atas asas kekeluargaan. Sebagaimana kegiatan usaha lainya, koperasi adalah badan usaha yang beranggotakan orang-seorang atau badan hukum Koperasi dengan melandaskan kegiatannya berdasarkan prinsip koperasi sekaligus sebagai gerakan ekonomi rakyat yang berdasar atas asas kekeluargaan (UU Republik Indonesia Tentang Perkoperasian Nomor 25 Tahun 1992: Pasal 1 ayat 1). Uraian diatas dapat garis bawahi yaitu : Pertama koperasi beranggotakan orang-seorang atau badan hukum koperasi. Koperasi beranggotakan orangseorang dibentuk dengan beranggotakan kumpulan orang minimal 20 orang untuk membentuk sebuah koperasi yang dinamakan koperasi primer (Undang-undang No. 25 tahun 1992, pasal 6 ayat 1). Kedua koperasi terdiri badan hukum koperasi adalah koperasi yang terdiri dari minimal 3 badan hukum koperasi membentuk sebuah koperasi sekunder (Undang-undang No. 25 tahun 1992, pasal 6 ayat 2 Tentang perkoperasiaan).

Selain itu koperasi mempunyai tanggung jawab untuk mengembangkan perekonomian nasional bersama-sama dengan pelaku-pelaku ekonomi lainnya. Namun koperasi mempunyai sifat-sifat khusus yang berbeda dari sifat bentuk perusahaan lainnya, maka koperasi menempati kedudukan yang sangat penting dalam sistem perekonomian Indonesia. Dengan demikian koperasi harus mempunyai kesungguhan untuk memiliki usaha yang sehat dan tangguh, sehingga 
dengan cara tersebut koperasi dapat mengemban amanat dengan baik (UU Republik Indonesia Tentang Perkoperasian Nomor 25 Tahun 1992 Pasal 4). Prinsip kerjasama Antar Koperasi. Koperasi dikatakan bersifat mandiri dan professional dalam pengorganisasiannya tetapi dalam menjalankan kegiatan usahanya koperasi tetap menjalin hubungan dan kerjasama antar koperasi berupa komunikasi dan interaksi baik secara langsung maupun tidak langsung. Kerjasama ini dimaksudkan untuk saling menguatkan usaha koperasi dengan koperasi yang lainnya. (UU Republik Indonesia Tentang Perkoperasian Nomor 25 Tahun 1992 Pasal 5).

Sampai saat ini banyak koperasi yang berdiri sampai tingkat desa namun kurang dikelola dengan baik. Hal ini berakibat pada kurangnya perannya koperasi dalam usaha mensejahterakan masyarakat. Apabila masyarakat dapat mengelola koperasi dengan baik, tentu saja akan meningkatkan kesejahteraan masyarakat pedesaan. Oleh karena itu perlu adanya pemahaman oleh masyarakat tentang bagaimana mengoptimalkan pengeloaan koperasi yang telah ada sehingga dapat mengingkatkan fungsi dan peran koperasi dalam usaha mensejahterakan masyarakat terutama di Kecamatan Gedangsari.

\section{METODE PELAKSANAAN}

Pelaksanaan kegiatan ini dilakukan dengan metode ceramah, workshop, dan role play sehingga peserta tidak hanya mendengarkan ceramah tetapi juga mendapatkan contoh, keterampilan dengan praktek secara langsung. Praktek dilaksanakan dengan memberi pelatihan pendirian badan hukum koperasi dan pelatihan simulasi perhitungan pinjaman pada lembaga keuangan. Ceramah diberikan dengan materi yang terdiri dari penyuluhan mengenai lembaga keuangan bagi masyarakat, penyuluhan meraih kesejahteran bersama koperasi, penyuluhan koperasi sebagai gerakan ekonomi rakyat, penyuluhan koperasi berprestasi, dan penyuluhan perkoperasian. Pelatihan yang akan diselenggarakan merupakan proses belajar dan berpikir aktif, oleh karena itu, dalam pelatihan ini akan diterapkan beberapa metode, diantaranya yaitu sebagai berikut:

1. Ceramah diberikan dengan materi perkoperasian yang terdiri dari materi yang terdiri dari penyuluhan mengenai lembaga keuangan bagi masyarakat, penyuluhan meraih kesejahteran bersama koperasi, penyuluhan koperasi sebagai gerakan ekonomi rakyat, penyuluhan koperasi berprestasi, dan penyuluhan perkoperasian.

2. Workshop, dilaksanakan dengan memberi pelatihan pendirian badan hokum koperasi dan pelatihan simulasi perhitungan pinjaman pada lembaga keuangan.

Sesi 1: Pengantar

Sesi 2: Penyuluhan mengenai lembaga keuangan bagi masyarakat

Sesi 3: Penyuluhan meraih kesejahteran bersama koperasi

Sesi 4: Penyuluhan koperasi sebagai gerakan ekonomi rakyat

Sesi 5: Penyuluhan koperasi berprestasi

Sesi 6: Penyuluhan perkoperasian 
Sesi 7: Pelatihan Simulasi Perhitungan Pinjaman Pada Lembaga Keuangan

\section{HASIL, PEMBAHASAN DAN DAMPAK}

Hasil dari kegiatan pengabdian program pengabdian masyarakat di Kecamatan Gedangsari Gunung Kidul adalah:

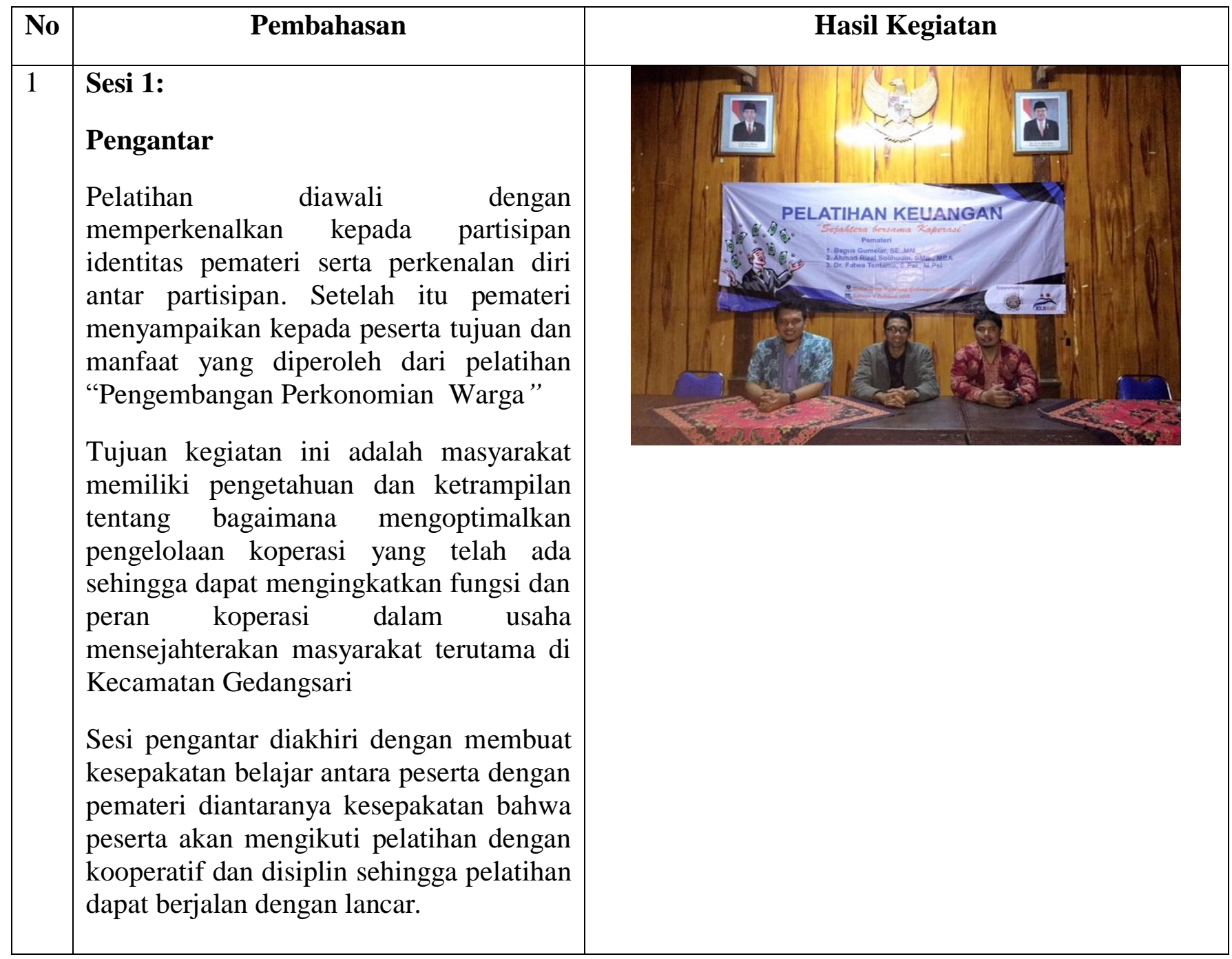




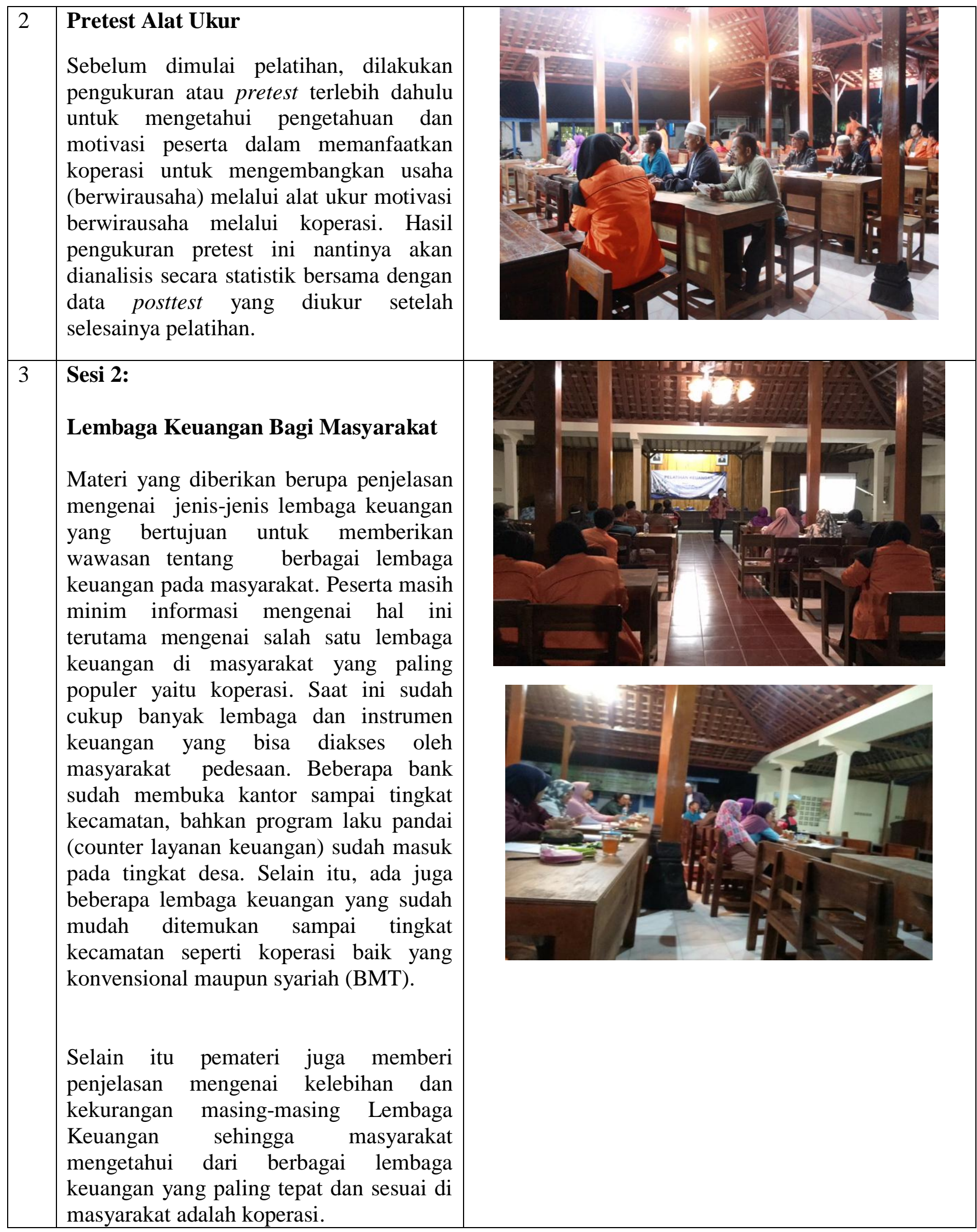


Sesi ini diakhiri dengan memutar video tentang literasi keuangan agar peserta dapat lebih mengenal tentang lembaga keuangan khususnya koperasi. Video ini memberikan contoh yang lebih riil agar peserta benar-benar memiliki gambaran secara jelas mengenai koperasi.

\section{Sesi 3:}

\section{Meraih Kesejahteran Bersama Koperasi}

Pada sesi ini pemateri secara umum memberi penjelasan mengenai definisi dan manfaat kesejahteraan. Peserta harus ditanamkan dahulu mengenai pemahaman dan konsep sejahtera sehingga dapat memiliki gambaran yang jelas dan memiliki motivasi untuk mewujudkan kesejahteraan tersebut. Selain itu peserta juga diberikan penjelasan mengenai bagaimana meraih kesejahteraan tersebut, langkah-langkah apa yang harus dilakukan untuk mewujudkannya. Pada sesi ini peserta semakin optimis dan tertarik untuk mengikuti pelatihan ini. Semua peserta ingin sejahtera tentunya.

Sesi ini diakhiri dengan materi yang lebih spesifik yaitu meraih kesejahteraan melalui koperasi. Menjelaskan manfaat koperasi bagi masyarakat dan peranannya dalam mensejahterakan anggotanya dan masyarakat luas

\section{Sesi 4:}

\section{Koperasi Sebagai Gerakan Ekonomi Rakyat}

Pada sesi ini pemateri menjelaskan pentingnya berkoperasi, koperasi sebagai lembaga keuangan mikro cukup tepat untuk wilayah pedesaaan. Selain karena
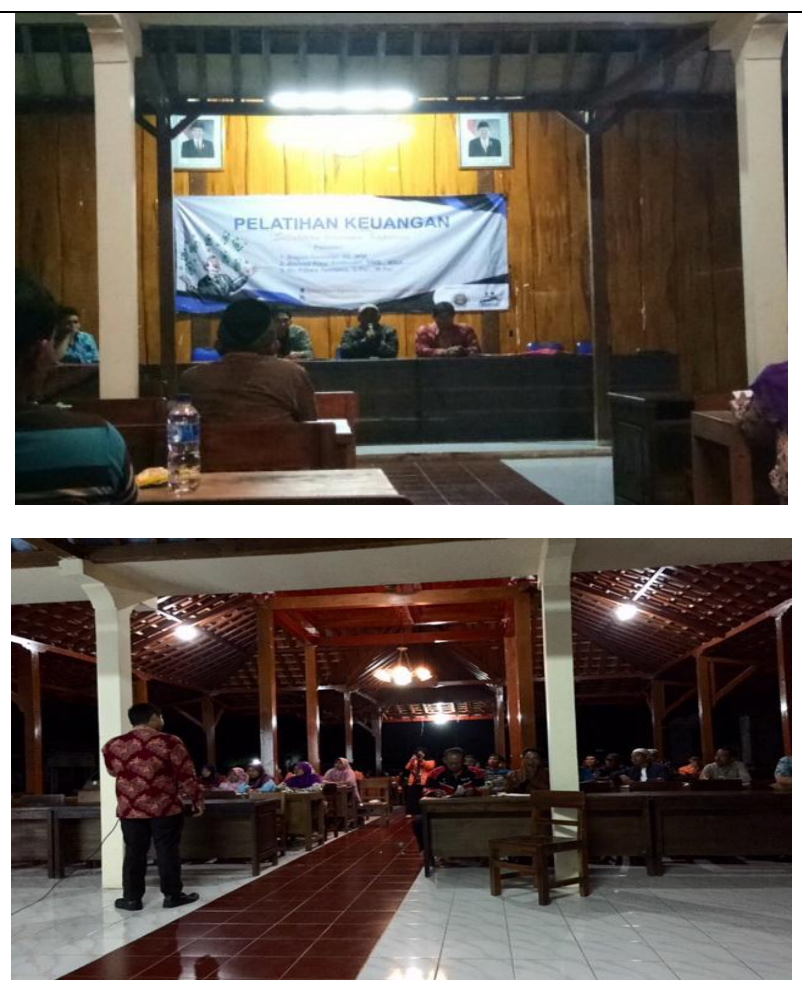


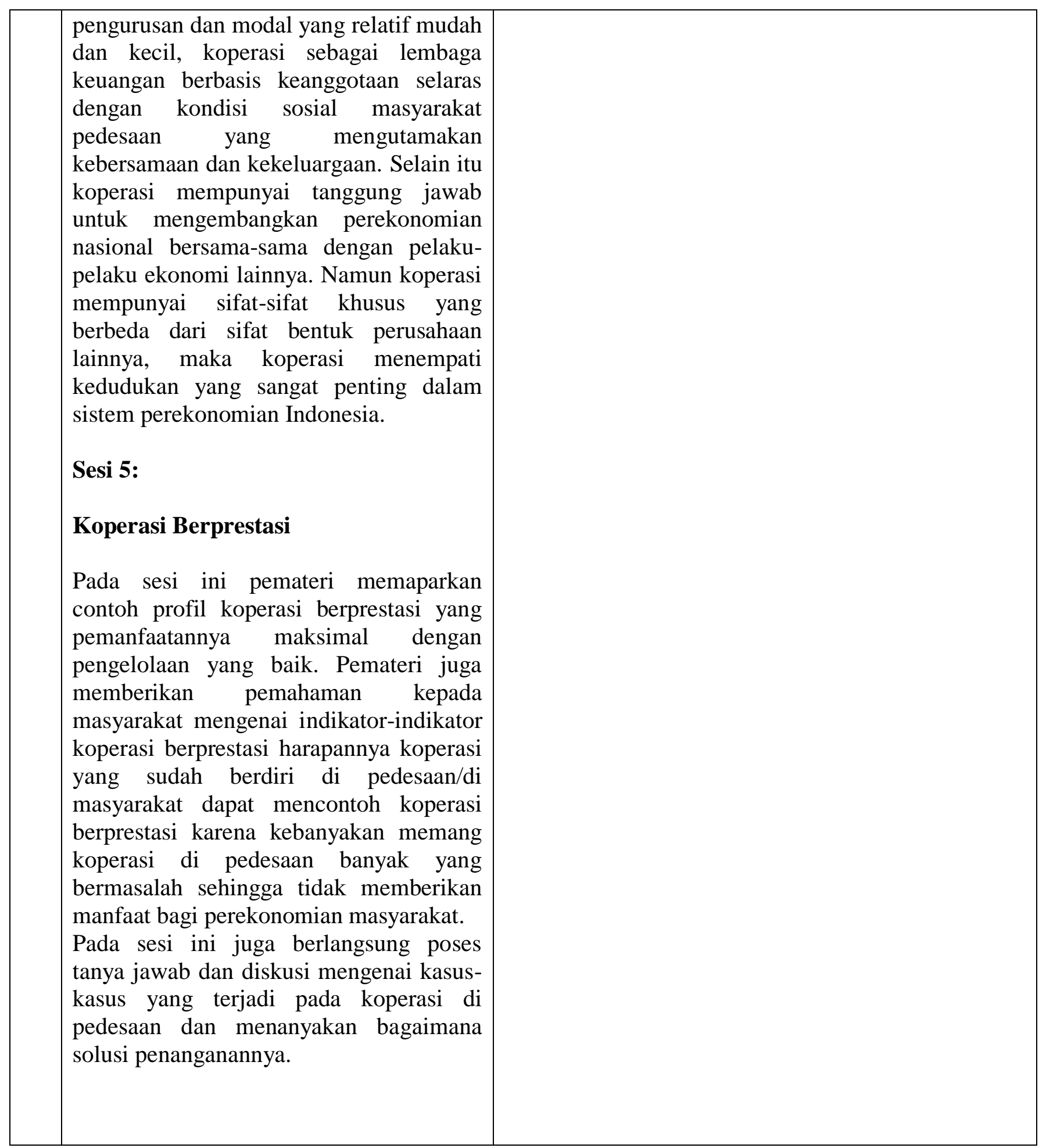




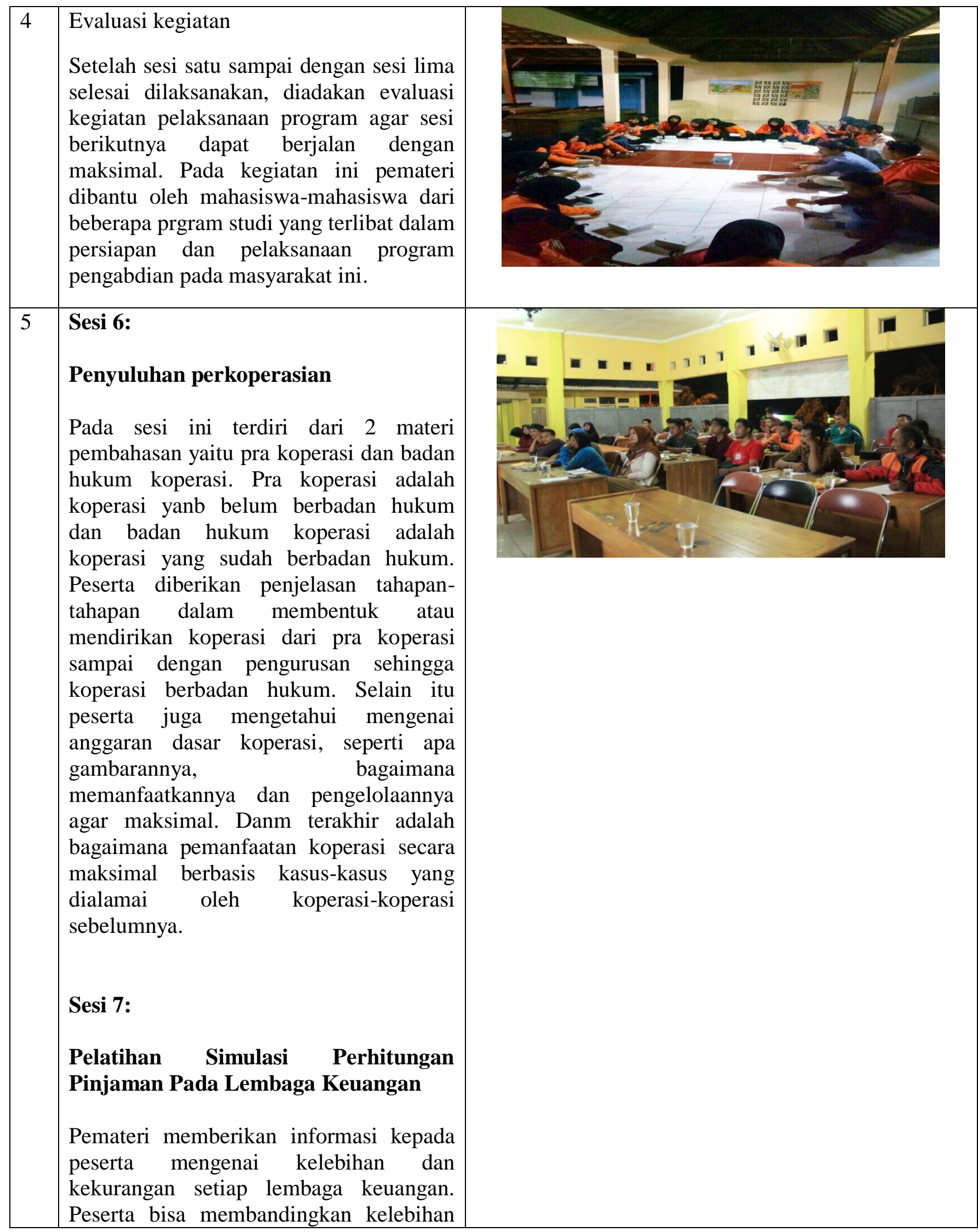




\begin{tabular}{|l|l|l|}
\hline dan kekurangan pembayaran bunga setiap \\
lembaga keuangan tersebut. Dan juga \\
memiliki ketrampilan dalam perhitungan \\
pinjaman khususnya pada koperasi \\
sehingga meminimalisasi terjadinya \\
resiko yang besar. Pada kesempatan ini \\
setiap peserta diberikesempatan \\
berdiskusi dan mempraktekkan dalam \\
melakukan perhitungan sederhana dalam \\
peminjaman uang. \\
$\begin{array}{l}\text { Penutup } \\
\text { (n) }\end{array}$
\end{tabular}

Dampak dari pelatihan ini masyarakat memiliki pemahaman tentang bagaimana mengoptimalkan pengelolaan koperasi yang telah ada sehingga dapat mengingkatkan fungsi dan peran koperasi dalam usaha mensejahterakan masyarakat terutama di Kecamatan Gedangsari serta memiliki pengetahuan dan ketrampilan dalam pendirian badan hukum koperasi dan melakukan perhitungan pinjaman pada lembaga keuangan. Selain itu masyarakat juga dapat memanfaatkan koperasi sebagai proses simpan pinjam sehingga terhindar dari peminjaman melalui rentenir yang saat ini berkembang didaerah Gunung Kidul khususnya kecamatan Gendangsari.

\section{KESIMPULAN}

Pemanfaatan koperasi sebagai lembaga keuangan mikro cukup tepat untuk wilayah pedesaaan dan kecamatan Gedangsari dapat dilakukan secara maksimal sehingga akan mengambat berkembangnya rentenir-rentenir di pedesaan. pengetahuan dan ketrampilan masyarakat dapat ditingkatkan dan fungsi-fungsi serta peran koperasi dapat dilakukan dengan baik. Setelah dilakukan kegiatan pengabdian ini diperlukan pendampingan secara berkelanjutan terhadap warga di kecamatan Gedangsari dalam memaksimalkan fungsi koperasi atau pendampingan dalam pendirian badan hukum koperasi. 


\section{DAFTAR PUSTAKA}

Undang-Undang Dasar 1945 pasal 33 ayat 1

UU Republik Indonesia Tentang Perkoperasian Nomor 25 Tahun 1992: Pasal 1 ayat 1

Undang-undang No. 25 tahun 1992, pasal 6 ayat 1 dan 2 Tentang perkoperasiaan

UU Republik Indonesia Tentang Perkoperasian Nomor 25 Tahun 1992: Pasal 4

UU Republik Indonesia Tentang Perkoperasian Nomor 25 Tahun 1992: Pasal 5

\section{UCAPAN TERIMAKASIH}

1. Universitas Ahmad Dahlan Yogyakarta untuk dukungannya sehingga program pengabdian masyarakat berjalan lancar.

2. LPPM Universitas Ahmad Dahlan Yogyakarta atas fasilitas, pengarahan dan pendampingannya selama berlangsungnya kegiatan 